Acta vet. scand. $1968,9,316-327$.

From the Indian Veterinary Research Institute. Izatnagar, U. P., India, and the Department of Medicine, Veterinary College of Norway, Oslo.

\title{
HAEMOGLOBIN AND ALBUMIN POLYMORPHISMS IN INDIAN WATER BUFFALOES
}

By

N. D. Khanna and M. Brænd

In recent years much work by use of electrophoretic techniques has been done on genetic variations of blood proteins in different livestock species, while very limited information is available on this aspect in water buffaloes. This species was reported to have two haemoglobin bands (Giri \& Pillai 1956, Vella 1958). Vella who investigated haemolysates from buffaloes in Bali also described traces of a third band in one individual. Two haemoglobin bands were further reported in Siamese water buffaloes (Loypetjra 1962) and in Indian water buffaloes (Sen et al. 1966). Naik \& Sukumaran (1967) reported the presence of one haemoglobin band in three buffaloes out of 350 tested. The rest had two bands.

Genetically controlled albumin polymorphism has been described in several animal species. McIndoe (1962) reported in chicken, Stormont \& Suzuki (1963), Brænd (1964) in horses, Ashton (1964), Ashton \& Lampkin (1965) in cattle, Efremov \& Brænd (1965a) in sheep.

The Indian water buffaloes are very important dairy, beef and draught animals of the Indian subcontinent, hence the present work.

\section{MATERIAL AND METHODS}

A total of 507 blood samples from the Murrah breed of Indian water buffaloes were collected from four buffalo breeding farms located at Izatnagar, Haringhata, Bikaner and Pantnagar. Of these 18 were from animals younger than 2 months. The samples 
were collected in an anticoagulant of isotonic sodium citrate. The protein separation was accomplished in horizontal starch gel electrophoresis. Gels were prepared with $10 \%$ potato starch, hydrolysed locally from commercial Norwegian starch. For haemoglobin separation, tris-EDTA-boric acid buffer (Gahne et al. 1960) at $\mathrm{pH} 8.9$ was used as electrode buffer. The same buffer diluted ten times was used as gel buffer. The insertions were done on filter paper. Bridges were from filter paper. The voltage output of power supply unit was $400 \mathrm{v}$ for gels of $20 \mathrm{~cm} \times$ $13 \mathrm{~cm} \times 0.4 \mathrm{~cm}$ dimension corresponding to $220 \mathrm{v}$ across the bridges. The gels were bisected horizontally and the lower half stained with benzidine solution. For separation of albumins several buffer systems were tried, but the discontinuous system described by Brænd \& Efremov (1965) was found to be the most satisfactory. The gels were prepared with five times diluted 0.19 $\mathrm{M}$ tris - $0.05 \mathrm{M}$ citric acid buffer at $\mathrm{pH} 5.8$ while $0.64 \mathrm{M}$ boric acid - $0.1 \mathrm{M}$ sodium hydroxide buffer at $\mathrm{pH} 7.8$ was used as bridge buffer. The starting voltage applied was $150 \mathrm{v}$, raised to $200 \mathrm{v}$ after $15 \mathrm{~min}$. for gels of above mentioned dimensions corresponding to 80 and $120 \mathrm{v}$ respectively between bridges. The staining was done with amido-black. Methanol-acetic acid-water (Smithies 1955) was used as destaining and fixative fluid.

Selected $\mathrm{Hb}$ samples were examined quantitatively by cellulose acetate electrophoresis (Brænd 1967).

\section{A. Haemoglobin}

\section{RESULTS}

Out of 507 individual samples tested 503 were observed with two bands and four samples showed three bands. All the calf samples (younger than two months) showed two bands of the same types as commonly found. The relationships between bands in 501 of the samples were so that the fastest component (which shall be called $A_{1}$ ) made about $67 \%$ whereas the slowest $\left(A_{2}\right)$ was about $33 \%$. In two of the two band samples the relationship was different, $A_{2}$ being considerably weaker.

The three different phenotypes are shown in Figs. 1a and $\mathbf{b}$. In Fig. 1a the most commonly occurring phenotype is shown together with the three band phenotype. The two fastest bands in the last mentioned type correspond in positions to the $A_{1}$ and $A_{2}$ bands. The $A_{1}$ band is, however, considerably weaker 

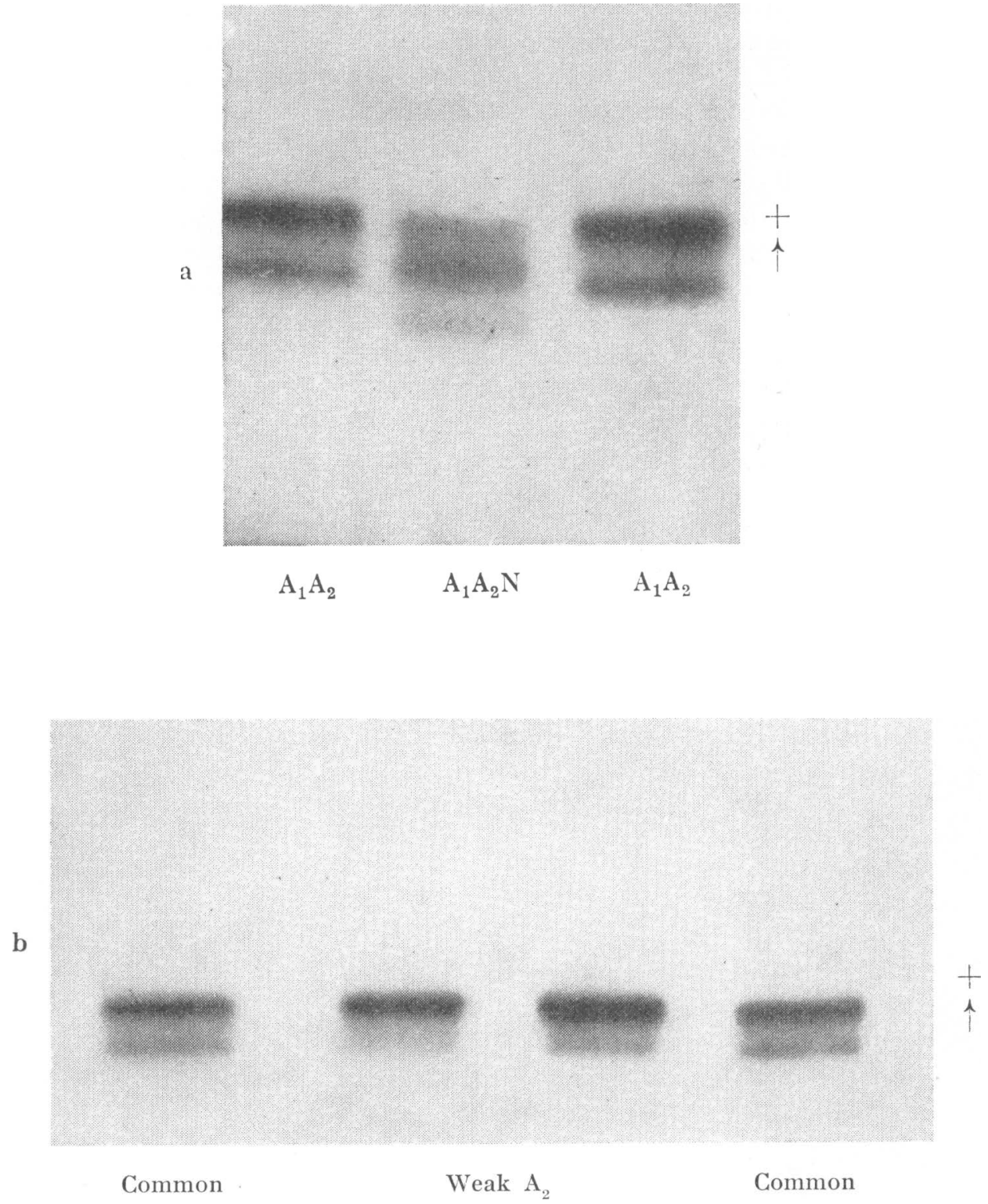

Figu r e 1. Photographs of stained starch gels showing (a) haemoglobin phenotypes, (b) variability in density of $A_{1}$ and $A_{2}$ haemoglobin bands in Indian water buffaloes. 
than the common $A_{1}$ band, and the third band which we tentatively shall call $\mathrm{N}$ is weaker than the common $A_{2}$ band.

The animals having three bands $\left(A_{1} A_{2} N\right)$ were of both sexes of varying ages and apparently healthy looking. Due to the low frequency of this phenotype limited family data were available. It can be mentioned, however, that the mother of one $A_{1} A_{2} N$ animal also was $A_{1} A_{2} N$ whereas the sire was $A_{1} A_{2}$. In another family the offspring of an $A_{1} A_{2} N$ cow was $A_{1} A_{2}$ after having been mated to an $A_{1} A_{2}$ bull.

The haemoglobin bands of the two animals having another relationship between $A_{1}$ and $A_{2}$ are shown in Fig. 1b. The concentrations vary, but compared with the common $A_{1} A_{2}$ type and judged by the unaided eye the $A_{2}$ band seems to be of about half the strength of what is found for the common $A_{1} A_{2}$ type.

These results may have any of several explanations. The occurrence of the same two band pattern $A_{1} A_{2}$ in the majority of animals indicates the existence of three polypeptide chains of which one is common for $A_{1}$ and $A_{2}$. Genetically, these may be governed by two structural genes only, but so that a mistranslation or an ambiguity causes the synthesis of two different chains. Balani \& Barnabas (1964) reported the common chain to be $\beta$, while the $\alpha$ chains of the two components differed. An amino acid substitution in the $\beta$ chain might therefore explain the retarded electrophoretic mobilities and the appearance of two other haemoglobin molecules. If the three common polypeptide chains tentatively are called $\alpha^{A_{1}}, \alpha^{A_{2}}$ and $\beta$ and the mutated one $\beta \mathrm{x}$ we should expect the four haemoglobin molecules: $\alpha_{2} \mathrm{~A}_{1} \beta_{2}, \alpha_{2} \mathrm{~A}_{2} \beta_{2}, \alpha_{2} \mathrm{~A}_{1} \beta_{2} \mathrm{X}, \alpha_{2} \mathrm{~A}_{2} \beta_{2} \mathrm{X}$. The occurrence of three components only may be due to the same rate of migration of the $\alpha_{2}{ }^{A_{2}} \beta_{2}$ and $\alpha_{2}{ }^{A_{1}} \beta_{2} \mathrm{X}$ molecules and thereby overlapping.

Another possible explanation is the assumption of three structural genes of which two are closely linked, each structural gene governing one polypeptide chain. This should theoretically result in the same electrophoretic picture as with the ambiguity theory.

The existence of animals with a different quantitative relationship between $A_{1}$ and $A_{2}$ bands than the common one resembles the situation in some horse breeds (Brænd \& Efremov 1965, Schmid 1965, Brænd 1967) where three phenotypes exist. One has one band only, $A_{1}$. In the two others there are differences in quantitative relationship with an average of $38 \% \mathrm{~A}_{2}$ in the one 
phenotype and $19 \% \mathrm{~A}_{2}$ in the other. Brænd (1967) proposed a modulating locus, $\mathrm{Hb}^{\mathrm{m}}$, being responsible for this variation either by working through inhibition of the synthesis of one of the polypeptide chains of $A_{2}$ or by eventually hindering a mistranslation to take place if we accept the ambiguity theory. The reported findings in buffaloes might be explained in the same way. In this connection it should be mentioned that Naik \& Sukumaran (1967) reported finding of water buffaloes with one band only.

As conclusion we therefore assume two different loci to be engaged in the control of the observed variation of water buffalo haemoglobin.

\section{B. Albumin}

Three types of phenotypes were observed for albumin when subjected to electrophoresis in acid $\mathrm{pH}$. The relative positions of these phenotypes are shown in Fig. 2.

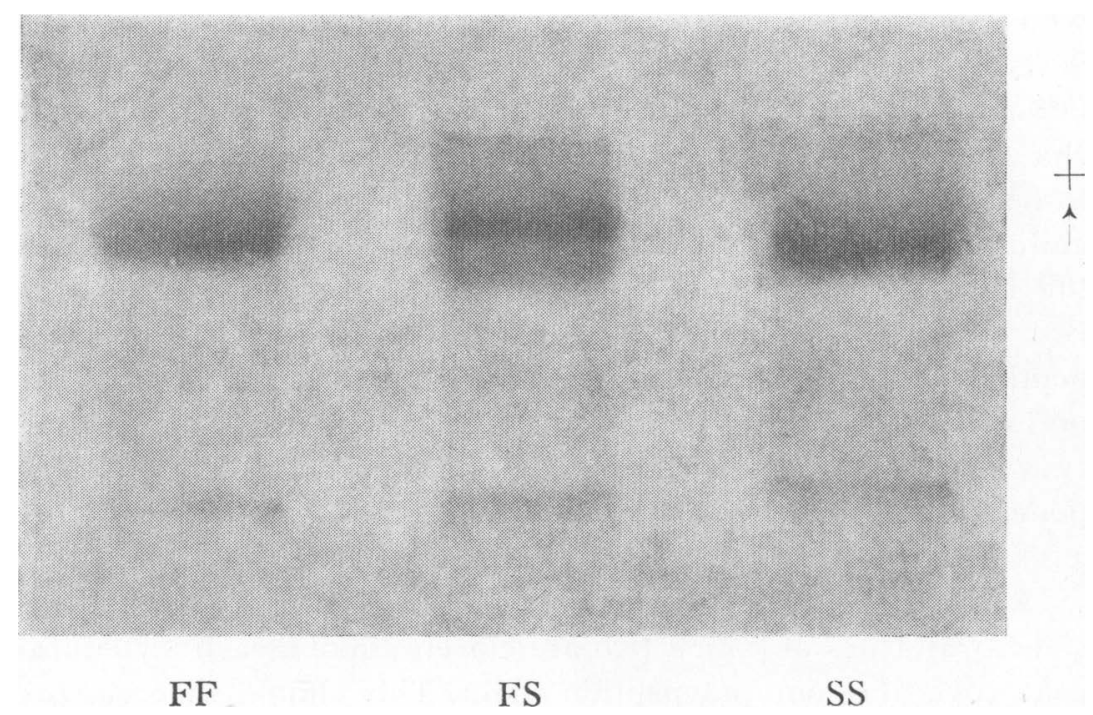

Figure 2. Photograph of stained starch gel showing different albumin phenotypes in water buffaloes.

The fastest single band towards the anode was designated as FF, while the slowest single band was denominated as SS. The intermediate type having two bands, i.e. one band having the mobility of FF and the other having mobility of SS, was termed as FS. The frequency of occurrence of these phenotypes is pre- 
Table 1. The frequency of different albumin phenotypes at four different buffalo breeding farms.

\begin{tabular}{|c|c|c|c|c|}
\hline \multirow{2}{*}{$\begin{array}{l}\text { Location } \\
\text { of farms }\end{array}$} & \multicolumn{4}{|c|}{ Albumin phenotypes } \\
\hline & FF & FS & SS & total \\
\hline Izatnagar & 3 & 37 & 166 & 206 \\
\hline Haringhata & 0 & 18 & 121 & 139 \\
\hline Bikaner & 0 & 14 & 29 & $43^{\star *}$ \\
\hline Pantnagar & 8 & 52 & 59 & $119^{\star \star}$ \\
\hline
\end{tabular}

* * Significant at $1 \%$ level.

sented in Table 1. An analysis was conducted to find out whether these frequencies differ significantly at different farms. The results showed that a significant difference existed between Pantnagar and the rest of the farms, and between Haringhata and Bikaner, while there was no significant deviation between Izatnagar and Haringhata farms. Therefore, the data from Izatnagar and Haringhata farms were pooled, and further analysis was conducted jointly. The data from Pantnagar was analyzed separately and Bikaner was excluded.

The data were further divided according to (i) sex and (ii) different age groups, viz. 0 to 1 year, 1 to 2 years, 2 to 3 years, and above 3 years and were subjected to $x^{2}$-test with a view to testing an eventual effect of these two characters on the frequency of different albumin phenotypes. The results are presented in Tables 2 and 3.

It may be seen from Table 2 that the $\chi^{2}$-values are not significant. It may be inferred, therefore, that sex has no detectable

Table 2. The effect of sex on the occurrence of albumin phenotypes in buffaloes.

\begin{tabular}{lccrrr}
\hline \multirow{2}{*}{$\begin{array}{l}\text { Albumin pheno- } \\
\text { types }\end{array}$} & \multicolumn{2}{c}{ Pantnagar } & & \multicolumn{2}{c}{ Pooled } \\
\cline { 2 - 5 } & males & females & males & females \\
\hline FF & 0 & 8 & 1 & 2 \\
FS & 1 & 51 & 9 & 46 \\
SS & 3 & 56 & 66 & 221 \\
Total & 4 & 115 & 76 & 269 \\
\hline$X^{2}$ & \multicolumn{2}{c}{1.15} & \multicolumn{2}{c}{1.41} \\
Probability & $.50<\mathrm{P}<.70$ & $.30<\mathrm{P}<.50$
\end{tabular}


Table 3. The effect of different age groups on the occurrence of albumin phenotypes in buffaloes.

\begin{tabular}{|c|c|c|c|c|c|c|c|c|}
\hline \multirow{2}{*}{ Age groups } & \multicolumn{4}{|c|}{ Pantnagar } & \multicolumn{4}{|c|}{ Pooled } \\
\hline & $\mathrm{FF}$ & FS & SS & total & FF & FS & SS & total \\
\hline 0 to 1 year & 1 & 7 & 8 & 16 & 1 & 11 & 60 & 72 \\
\hline 1 to 2 years & 2 & 3 & 8 & 13 & 0 & 7 & 68 & 75 \\
\hline 2 to 3 years & 0 & 1 & 2 & 3 & 1 & 7 & 39 & 47 \\
\hline Above 3 years & 5 & 41 & 41 & 87 & 1 & 30 & 120 & 151 \\
\hline Total & 8 & 52 & 59 & 119 & 3 & 55 & 287 & 345 \\
\hline
\end{tabular}

$\begin{array}{lcc}\chi^{2} & 4.02 & 6.11 \\ \text { Probability } & .50<\mathrm{P}<.70 & .30<\mathrm{P}<.50\end{array}$

effect on the frequencies of albumin phenotypes in any of the two populations.

The results presented in Table 3 indicate that significant differences do not exist between different age groups as to frequencies of albumin phenotypes.

In an attempt to study the mode of inheritance of albumin phenotypes all animals whose family records were available were picked out. The results indicate that two codominant autosomal alleles, viz. $\mathrm{Al}^{\mathrm{F}}$ and $\mathrm{Al} S$ are involved in the control of the albumin variation in water buffaloes. The observed phenotypes of the offspring were in consistency with the assumed hypothesis. It was, however, observed that under the mating FS $\times$ SS a higher number SS individuals than expected was observed, with an excess of offspring having genotype as that of the dam.

Table 4. The observed and expected phenotypes and gene frequencies of albumin polymorphism in Murrah breed of Indian buffaloes.

\begin{tabular}{|c|c|c|c|c|c|c|c|c|c|}
\hline \multirow{3}{*}{ Population } & \multicolumn{6}{|c|}{ Albumin phenotypes } & \multirow{3}{*}{$\chi^{2}$} & \multirow{3}{*}{ Probability } & \multirow{3}{*}{$\begin{array}{l}\text { Frequencies } \\
\qquad \mathrm{Al}^{\mathrm{F}}\end{array}$} \\
\hline & \multicolumn{2}{|c|}{ FF } & \multicolumn{2}{|c|}{ FS } & \multicolumn{2}{|c|}{ SS } & & & \\
\hline & Obs. & Exp. & Obs. & Exp. & Obs. & Exp. & & & \\
\hline Pantnagar & 8 & 10.0 & 52 & 49.0 & 59 & 60.0 & 0.60 & $.30<\mathrm{P}<.50$ & 0.29 \\
\hline Pooled & 3 & 2.8 & 55 & 56.5 & 287 & 285.7 & 0.06 & $.80<\mathrm{P}<.90$ & 0.09 \\
\hline
\end{tabular}

Very good agreement between observed and expected values of different albumin phenotypes was observed. It may therefore be said that both populations are in genic equilibrium for the albumin genes. The gene frequencies for $\mathrm{Al}^{\mathrm{F}}$ and $\mathrm{Al}^{\mathrm{S}}$ were found 
to be 0.29 and 0.71 respectively at Pantnagar and 0.09 and 0.91 respectively for the pooled population. The difference in the two populations may be due to herd to herd variations.

\section{DISCUSSION}

The commonly occurring two band $\mathrm{Hb}$ phenotype in water buffalo is very similar in appearance on starch gels to the most common two band $\mathrm{Hb}$ phenotype in horses (Brænd 1967) and the $\mathrm{Hb}$ phenotype of European bison (Brænd \& Gasparski 1967). As a genetic explanation for the two $\mathrm{Hb}$ bands in horses, Kilmartin \& Clegg (1967) proposed an ambiguity in the translation of an RNA codon. This theory was based upon their findings of heterogeneity at two different places, positions 24 and 60 in the $\alpha$ chains, making a total of four different $\alpha$ chains, while the $\beta$ chains were identical. Ambiguity or mistranslation has also been proposed as an explanation for multiple $\alpha$ chains in the rabbit (Ehrenstein 1966) and in the mouse (Rifkin et al. 1966, Popp 1967). Within the two last species the $\beta$ chains were also identical. This is in contrast to the "normal" haemoglobins of man (see Ingram 1963), cattle (Efremov and Brænd 1965b, Schroeder et al. 1967) and sheep (Huisman 1967) where the $\alpha$ chains are identical.

The observed three band variant shows a starch gel phenotype very similar in appearance to that of the European bison-cattle hybrid (Brænd \& Gasparski). For the occurrence of the three bands in the hybrid a probable explanation (Brænd, unpublished) is heterozygosity at a modulating locus. Whether such a modulating locus in the hybrid is working through inhibition of the synthesis of one of the polypeptide chains of the slowest component $\mathrm{A}_{2}$ or whether it works on an eventual ambiguity or mistranslation mechanism is another question. Within the species of water buffalo, however, heterozygosity at a modulating locus cannot explain the three band phenotype, hence the theory of the variant structural gene for the $\beta$ chain.

The difference in quantitative relationship between $A_{1}$ and $A_{2}$ which was observed in a few animals can in our opinion best be explained by heterozygosity at a modulating locus in the same way as for horses (Brænd 1967). The lack of the one band phenotype in our material is according to expectation due to the low frequency of the heterozygote. The one band type is, however, reported by Naik \& Sukumaran (1967). 
Genetically determined albumin variation has now been reported for many species. In man, European cattle and sheep most individuals are homozygous for the common type. The number of different variants, however, increase with the extent of the investigations. Thus in man (Weitkamp et al. 1967) at least four variants exist, in African cattle also at least four (Ashton \& Lampkin 1965, Carr 1967). In sheep two variants are so far reported (Efremov \& Brænd 1965a, Tucker 1968). In horses two alleles have been reported both at high frequencies (Stormont \& Suzuki 1963, Brænd \& Efremov 1965, Gahne 1966). In water buffaloes the rare allele $\mathrm{Al}^{\mathrm{F}}$ occurred at a rather high frequency, and as in horses the polymorphism can be considered a true polymorphism according to Ford (1945). Why we have such differences between species is not understood at the moment, but on the other hand they are more the rule than the exception for many serum protein systems. Perhaps results from comparative investigations might help us to a better understanding of the forces involved in the maintenance of polymorphisms thereby putting us in a better position in the matter of improving our livestock species.

\section{REFERENCES}

Ashton, G. C.: Serum albumin polymorphısm in cattle. Genetics 1964, $50,1421-1426$.

Ashton, G. C. \& G. H. Lampkin: Serum albumin and transferrin polymorphism in East African cattle. Nature (Lond.) 1965, 205, $209-210$.

Balani, A. S. \& J. Barnabas: Evaluation of multiple haemoglobins of ruminants by tryptic peptide pattern analysis. Indian J. Biochem. 1964, 1, 220-224.

Brænd, M.: Serum types of Norwegian horses. Nord. Vet.-Med. 1964, $16,363-373$.

Brænd, M.: Genetic variation of horśe hemoglobin. Hereditas (Lund) 1967, 58, 385-392.

Brænd, M. \& G. Efremov: Haemoglobins, haptoglobins and albumins of horses. Proc. 9th Europ. Animal Blood Grp. Conf., Prague $1965,253-259$.

Brænd, M. \& J. Gasparski: Haemoglobins and transferrins of European bison and their cattle hybrids. Nature (Lond.) 1967, 214, 98-99.

Carr, W. R.: Serum albumin polymorphism of some breeds of cattle in Zambia. Proc. 10th Europ. Animal Blood Grp. Conf., Paris 1967, 293-297.

Efremov, G. \& M. Brænd: Haemoglobins, transferrins and albumins of sheep and goats. Proc. 9th Europ. Animal Blood Grp. Conf., Prague 1965a, 313-320. 
Efremov, G. \& M. Brænd: Differences in cattle globins. Biochem. J. 1965b, 97, 867-869.

Ehrenstein, G. von: Translational variations in the amino acid sequence of the $\alpha$-chain of rabbit hemoglobin. Cold Spring Harbor Symp. 1966, 31, 705-714.

Ford, E. B.: Polymorphism. Biol. Rev. 1945, 20, 73-88.

Gahne, B.: Studies on the inheritance of electrophoretic forms of transferrins, albumins, prealbumins and plasma esterases of horses. Genetics 1966, 53, 681-694.

Gahne, B., J. Rendel \& O. Venge: Inheritance of $\beta$-globulins in serum and milk from cattle. Nature (Lond.) 1960, 186, 907-908.

Giri, K. V.\& N. C. Pillai: Multiple hæmoglobins in the blood of animals. Nature (Lond.) 1956, 178, 1057.

Huisman, T. H. J.: Hemoglobin types in some domestic animals. Proc. 10th Europ. Animal Blood Grp. Conf., Paris 1967, 61-75.

Ingram, V. M.: The hemoglobins in genetics and evolution. Columbia University Press, New York 1963, pp. 116.

Kilmartin, J.V.\& J. B. Clegg: Amino-acid replacements in horse haemoglobin. Nature (Lond.) 1967, 213, 269-271.

Loypetjra, P.: Undersøgelser over blodtyper samt hæmoglobin- og serumtyper hos thailandske vandbøfler. Kgl. Vet.- og Landbohøjsk., Inst. Sterilitetsforskn. Aarsberetn. 1962, 221-226. København.

McIndoe, W. M.: Occurrence of two plasma albumins in the domestic fowl. Nature (Lond.) 1962, 195, 353-354.

Naik, S. N. \& P. K. Sukumaran: Haemoglobin polymorphism in Indian water buffaloes. Proc. 10th Europ. Animal Blood Grp. Conf., Paris 1967, 401-405.

Popp, R. A.: Hemoglobins of mice. Sequence and possible ambiguity at one position of the alpha chain. J. Mol. Biol. 1967, 27, 9-16.

Rifkin, D. B., M. R. Rifkin \& W. Konigsberg: The presence of two major hemoglobin components in an inbred strain of mice. Proc. nat. Acad. Sci. (Wash.) 1966, 55, 585-592.

Schmid, D. O.: Über den Hämoglobin-Polymorphismus beim Pferd. Z. Immun.-Allergieforsch. 1965, 128, 499-503.

Schroeder, W. A., J. R. Shelton, J. B. Shelton, B. Robberson \& D. R. Babin: A comparison of amino acid sequences in the $\beta$-chains of adult bovine hemoglobins A and B. Arch. Biochem. 1957, 120, 124-135.

Sen, A., D. Roy, S. Bhattacharya \& N. C. Deb: Hemoglobins of Indian Zebu cattle and the Indian buffalo. J. Animal Sci. 1966, 25, 445448.

Smithies, O.: Zone electrophoresis in starch gels. Biochem. J. 1955, 61, $629-641$.

Stormont, C. \& Y. Suzuki: Genetic control of albumin phenotypes in horses. Proc. Soc. exp. Biol. (N.Y.) 1963, 114, 673-675. 
Tucker, E. M.: Personal communication 1968.

Vella, F.: Hæmoglobin types in ox and buffalo. Nature (Lond.) 1958, $181,564-565$.

Weitkamp, L. R., D. C. Shreffler, J. L. Robbins, O. Drachmann, P. L. Adner, R. J. Wieme, N. M. Simon, K. B. Cooke, G. Sandor, F. Wuhrmann, M. Brænd \& A. L. Tárnoky: An electrophoretic comparison of serum albumin variants from nineteen unrelated families. Acta genet. (Basel) 1967, 17, 399-405.

\section{SUMMARY}

A total of 507 samples from the Murrah breed of Indian water buffalo were examined for haemoglobin and albumin polymorphism using starch gel electrophoresis. The majority of samples showed the same two band haemoglobin phenotype, $A_{1} A_{2}$, where the fastest band $A_{1}$ was about $67 \%$ of total haemoglobin. Two rare phenotypic haemoglobin variants were observed. The one, found in four animals, had three bands and is explained by mutation in the $\beta$ chain. The other, found in two animals, showed another relationship between the $A_{1}$ and $A_{2}$ bands than the common type and is assumed to be caused through heterozygosity at a modulating locus. Three albumin phenotypes were observed. Family data were in agreement with these being controlled by two codominant alleles, called $\mathrm{AlF}$ and $\mathrm{AlS}$. Frequency of $\mathrm{AlF}^{\mathrm{F}}$ was 0.09 and 0.29 in two different populations. Age and sex did not have any effect on distribution of albumin phenotypes.

\section{ZUSAMMENFASSUNG}

Hämoglobin- und Albumin-Polymorphie bei indischem Wasserbüffel.

Insgesamt sind 507 Proben von indischem Wasserbüffel, Murrah Rasse, auf Hämoglobin- und Albumin-Polymorphie mit Hilfe von Stärkegel-Elektrophorese untersucht worden. Der grösste Teil der Proben zeigte denselben zwei-Band-Hämoglobinphänotyp, $A_{1} A_{2}$, in dem das schnellste Band, $A_{1}, 67 \%$ der gesamten Hämoglobinmenge ausmachte. Es wurden zwei seltene phänotypische Hämoglobinvarianten gefunden. Der eine, der bei vier Tieren festgestellt wurde, hatte drei Bänder und wird durch eine Mutation in der $\beta$-Kette erklärt. Der andere, der bei zwei Tieren festgestellt wurde, zeigte ein anderes Verhältnis zwischen den $A_{1}$ - und $A_{2}$-Bändern als der gewöhnliche Typ. Es wird angenommen, dass dieses Verhältnis von einer Heterozygotie in einem modulierenden Lokus verursacht wird. Drei Albumin-Phänotypen wurden festgestellt. Familien-Untersuchungen deuteten darauf hin, dass diese allem Auschein nach von zwei kodominanten Allelen, $\mathrm{AlF}^{\mathrm{F}}$ und $\mathrm{AlS}$ genannt, kontrolliert werden. Die Häufigkeit von $\mathrm{Al}^{\mathrm{F}}$ war in zwei verschiedenen Populationen 0,09 bzw. 0,29. Alter und Geschlecht zeigten keinen Effekt in bezug auf die Verteilung von Albumin-Phänotypen. 


\section{SAMMENDRAG}

Hemoglobin- og albumin-polymorfisme hos indisk vannbøffel.

I alt 507 prøver fra indisk vannbøffel, Murrah rase, er blitt undersøkt for hemoglobin- og albumin-polymorfisme ved hjelp av stivelsesgel - elektroforese. Storparten av prøvene viste den samme to bånd hemoglobinfenotype, $A_{1} A_{2}$, hvor det hurtigste bånd, $A_{1}$, utgjorde omtrent $67 \%$ av totalt hemoglobin. Det ble funnet to sjeldne fenotypiske hemoglobin varianter. Den ene som ble påvist hos fire dyr hadde tre bånd og er forklart ved mutasjon i $\beta$-kjeden. Den andre som ble funnet hos to dyr viste et annet forhold mellom $A_{1}$ og $A_{2}$ båndene enn $i$ den vanlige type og er antatt å være forårsaket ved heterosygoti $i$ et modulerende lokus. Tre albumin-fenotyper ble funnet. Familie-unders $\varnothing \mathrm{kel}-$ ser viste overensstemmelse med at disse er kontrollert av to kodominante alleler, kalt $\mathrm{AlF}$ og $\mathrm{AlS}$. Hyppighet av $\mathrm{AlF}$ var 0,09 og 0,29 i to forskjellige populasjoner. Alder og kjønn viste ingen effekt med hensyn til distribuering av albumin fenotyper.

(Received May 24, 1968). 